\title{
Occurrence of gypsy moth (Lymantria dispar L.) in the Slovak Republic and its outbreaks during 1945-2020
}

\author{
Milan Zúbrik ${ }^{1 *}$, Andrej Kunca ${ }^{1}$, Ján Kulfan ${ }^{2}$, Slavomír Rell ${ }^{1}$, Christo Nikolov ${ }^{1}$, Juraj Galko ${ }^{1}$, \\ Jozef Vakula ${ }^{1}$, Andrej Gubka ${ }^{1}$, Roman Leontovyč ${ }^{1}$, Bohdan Konôpka ${ }^{1}$, Michal Lalík ${ }^{1}$, Valéria \\ Longauerová $^{1}$, Zuzana Sitková ${ }^{5}$, Jan Liška ${ }^{3}$, Peter Zach ${ }^{2}$, Marek Barta ${ }^{2}$, Jaroslav Holuša ${ }^{4}$ \\ ${ }^{1}$ National Forest Centre, Forest Protection Service, Lesnícka 11, SK-969 23 Banská Śtiavnica, Slovak Republic \\ ${ }^{2}$ Institute of Forest Ecology, Slovak Academy of Sciences, L. Štúra 2, SK-960 53 Zvolen, Slovak Republic \\ ${ }^{3}$ Forestry and Game Management Research Institute, CZ - 15600 Prague 5 - Zbraslav, Czech Republic \\ ${ }^{4}$ Czech University of Life Sciences Prague, Faculty of Forestry and Wood Sciences, Kamýcká 1176, \\ CZ - 16521 Prague 6 - Suchdol, Czech Republic \\ ${ }^{5}$ National Forest Centre - Forest Research Institute Zvolen, T. G. Masaryka 2175/22, SK-96901 Zvolen, Slovak Republic
}

\begin{abstract}
The gypsy moth is one of the most serious pests in forests and fruit tree plantations over prevailing parts of the Northern Hemisphere. This work is based on a literature review, and presents history of gypsy moth Lymantria dispar L., observed in Slovak forests within the period 1945-2020. The life cycle, hosts, natural enemies, population dynamics of pests, impact of outbreaks on forests and different management methods used in the past are discussed. Since 1945, there were nine gypsy moth outbreaks in Slovakia. Between 1945 and 2020, a total of 155,034 ha of deciduous forests were touched with varying intensity, representing an average annual damage of 2,040 ha. The strongest outbreak culminated in 2004 . Totally 51,479 ha were attacked in the period of 2000-2008. We have found outbreak periods that repeat with frequency of $7.8 \pm 2.2$ years and the average outbreak phase lasts $3.1 \pm 1.1$ years. The period between two subsequent outbreaks seems to be more or less constant and duration of the outbreak phase seems to be gradually shortened during the study period. Several factors influencing the gypsy moth population dynamics in Slovakia are discussed. The role of biological control by using entomopathogenic fungus Entomophaga maimaiga is described.
\end{abstract}

Key words: population dynamics leaf-eating insect; periodic outbreaks; natural enemies; Entomophaga maimaiga

Editor: Jiří Foit

\section{Introduction}

The gypsy moth Lymantria dispar L. (Lepidoptera: Erebidae) is one of the most serious forest insect pests, but also of fruit trees across much of the Northern Hemisphere. Large areas damaged by the gypsy moth are reported from the Northeastern United States and Asia (Schedl 1936; Doane \& McManus 1981; McManus \& Csóka 2007; Zúbrik et al. 2013). The cyclic gypsy moth outbreaks (Hlásny et al. 2015) resulted in loss of radial growth (Muzika \& Liebhold 1999), changes in fruiting (Gottschalk 1990), and if repeated, in tree mortality in subsequent years (Patočka \& Novotný 1985; Davidson et al.1999). In Southeast Europe, outbreaks are more frequent (Perneket al. 2008) and more intense (McManus \& Csóka 2007) than in Central Europe (Hlásny et al. 2015).

Over the period of 1945-2016, more than 0.5 million hectares was damaged in different ways by leaf-eating insects in Slovakia (Zúbrik et al. 2017a). The gypsy moth ranked among key insect pests that feed on leaves in forests of Slovakia during the study period, along with Operophtera brumata L., Erannis defoliaria Clerck, Agriopis leucophaearia Denis \& Schiffermüller, Tortrix viridana L., Orthosia spp., Choristoneura murinana Hübner, Epinotia nigricana Herrich-Schäffer, Diprion pini L., Diprion spp., Melolontha spp., and some other species (Turček 1956; Charvát \& Patočka 1960; Čapek 1961; Patočka 1955, 1963a, b, 1967a, 1973; Leontovyč et al. 1980; Surovec et al. 1989; Zúbrik 2006; Zúbrik et al. 2015, 2017a, b;Vakula et al. 2015; Sarvašová et al. 2020). Some species, such as Pristiphora laricis Hartig, Rhyacionia buoliana Denis \& Schiffermüller or Coleophora laricella Hübner, have caused damage to trees only occasionally and only in relatively restricted areas (Leontovyč et al. 1980; Surovec et al. 1989; Zúbrik et al. 2017b). 
Despite direct effect of defoliation on the tree mortality is questionable, often defoliated drought-stressed trees increase their secondary mortality caused by other pests such as Scolytus intricatus Ratzeburg (Coleoptera: Scolytinae), Agrilus spp. as well as other species of jewel beetles (Coleoptera: Buprestidae) and long-horned beetles (Cerambycidae), etc., developing frequently and abundantly in weakened trees (Novotný 1986; Zach 1994; Patočka et al. 1999). In the 70s and 80s of the last century, oak stands in Slovakia, were heavily affected by tracheomycosis disease (Leontovyč 1980; Surovec et al. 1989). Tracheomycosis disease and also armillaria root disease (Armillaria spp.) significantly reduce the ability of oak stands to resist defoliation caused by gypsy moth.

The aim of this study was to summarise the more detailed information on the gypsy moth in Slovakia, in particular: to reconstruct its population dynamics, analyse data about life cycle, hosts, natural enemies, impacts on forests and evaluate other significant aspects related to its biology and ecology over the period of 1945-2020. All these aspects are discussed in the context of theoretical knowledge, and practical expertise obtained from sources in Slovakia and others being external. Data from Slovakia are discussed with those, known from other areas of gypsy moth occurrence.

\section{Methods}

\subsection{Data sources}

To obtain the data we used three main sources for this work.

A) The primary source was the data present in different scientific and expert publications. Accurate information about the gypsy moth presence from the period 1945 1960 is lacking. Most of the data were available on the country level. We also used information about local gradations, determined by a place, or certain locality. These data are based on published estimations. Recent data, in papers published over the last 50 years are of higher accuracy.

B) For the period since 1961, we used official statistical records reported by forest managers. Damages were recorded on the accuracy level of the forest districts or country district (Zúbrik et al. 1999).

C) The most accurate data were obtained through monitoring conducted by forest managers and supervised by the Forest Protection Service in the frame of relevant projects, as our observations and experience.

We analyzed data from all the above-mentioned sources to reconstruct the long-term trend of the gypsy moth population occurrence in Slovakia. After analysing the data from all these three sources $(A, B, C)$, we constructed a table with the estimated area, damaged by gypsy moth per years.

To define temperature and precipitation trends, we analysed the data from the Slovak Hydrometeorological
Institute (SHMÚ) in Bratislava. Average monthly temperatures and precipitation data recorded at 26 weather stations (Gabčíkovo, Bratislava Airport, BratislavaKoliba, Dolné Plachtince, Dubník, Dudince, Holíč, Hurbanovo, Komárno, Králová pri Senci, Kuchyňa, Leles, Lučenec, Malacky, Malé Ripňany, Moldava nad Bodovu, Nitra, NovýTekov, Podhájska, Rimavská Sobota, Somotor, Štúrovo, Tesárske Mlyňany, Trnava, Žihárec) over the period of 1931-2015 were used. The presence of the gypsy moth in the area was the criterion for including a particular weather station in the analysis. Data were smooth using Local Polynomial Regression Fitting.

\subsection{Terms}

In order to be as precise as possible and to avoid confusion due to unclear terms, we provide a short explanation of some of the most commonly used terms (Fig. 1). We defined 'outbreak', 'outbreak length' or 'outbreak period length' respectively, as a period, during which gypsy moth caused certain damages in the forest (higher than zero). During building and declining phase of outbreak, gypsy moth population density often remains on a very low level for a long time. For that reason we also introduce a term "outbreak phase". We defined it as a period, during which more than 1,000 ha of forest stands was damaged annually. This rule was not applied to the period 2013-2014 and 2017-2020. During this period, only minor areas were damaged, but we nevertheless, for certain reasons mentioned in the article, decided to label the events as outbreaks of the gypsy moth. The 'outbreak peak' is considered the year, with the highest registered damage during the outbreak period (Fig. 1). If we speak about "outbreak frequency", we mean the period between two outbreak peaks.

\subsection{Statistics and data presentations}

For common statistics and data interpretation, we used Microsoft Excel 2016. We used mean, standard deviation (mean \pm standard deviation) and coefficient of determination calculated in this program. Trend lines were calculated using the method of least squares in the same program. For picture processing, and figure elaborating we used Adobe Photoshop ${ }^{\circledR}$ (2016) and R Studio, version 1.3.1093, package ggplot2 Wickham (2016).

\section{Gypsy moth life cycle}

In Slovakia, the gypsy moth prefers older forest stands that are under warmer conditions in the southwestern and southern regions of the country, as well as in the eastern lowlands. It can also be found in dry localities, on steep slopes, in sparse and in wet-mesic floodplain forests along rivers (Turček 1956; Stolina 1985; Novotný \& Turčáni 1992; Patočka et al. 1999). 


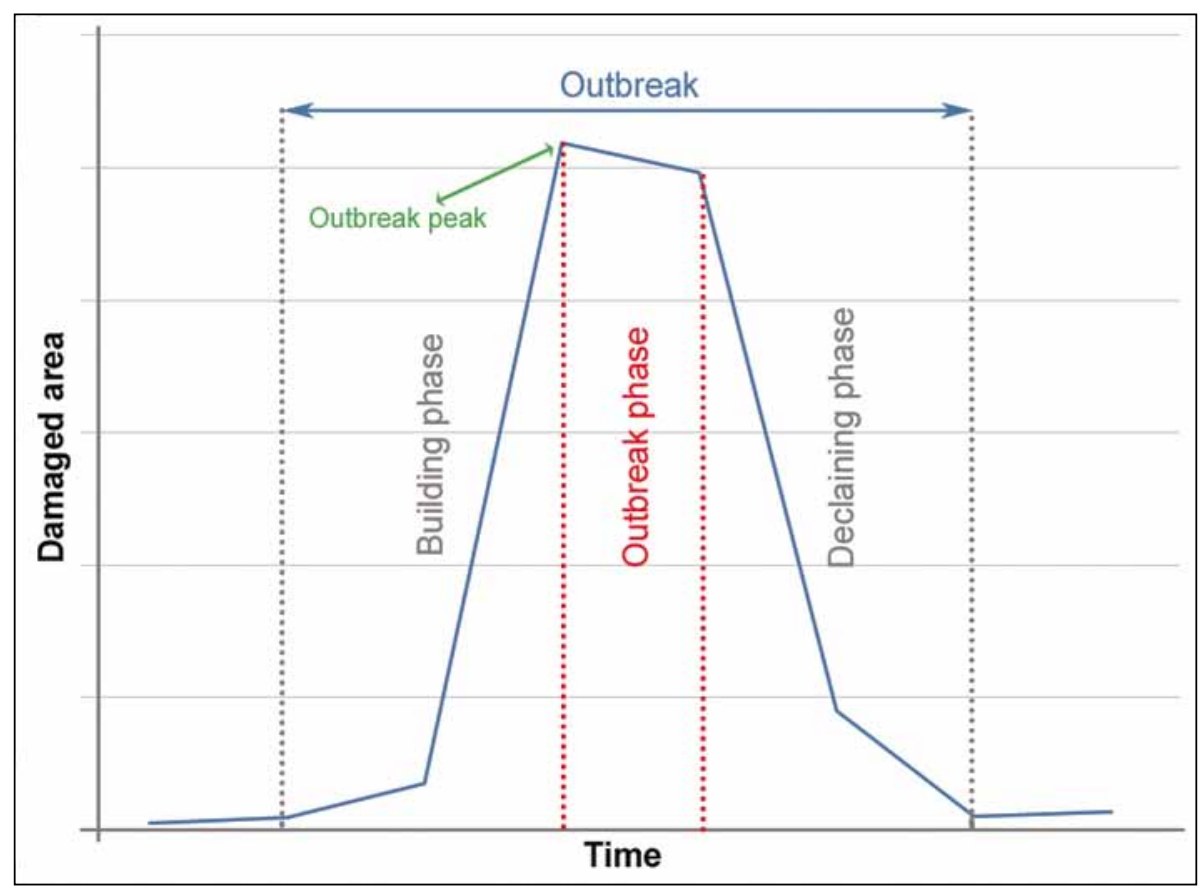

Fig. 1. Gypsy moth outbreak phases.

The gypsy moth has one generation per year. Adults (Fig. 2) are on the wings from July to August (from middle June to early September in recent years). Females lay eggs (Fig. 2) preferably at the base of the tree trunk although, during an outbreak, they do it also high in the crowns and even on thin branches (Turček 1956; Patočka 1961, 1973; Novotný 1986; Zúbrik 2006; Vakula et al. 2015). For assessing pest density on a plot, the Turček's method (based on egg masses count) is commonly used (Turček 1956), later this being changed slightly in forest documents that are officials (STN 43 2715). During an outbreak period, average number of egg masses per tree can reach 20 to 30 clusters (Hoch et al. 2001; Zúbrik, 2006), but it can be in some exceptional cases even more, 30 to 70 in heavily infested stands (Patočka 1973; Novotný 1986; Novotný \& Turčáni 1992; Zúbrik \& Novotný 1997). Patočka (1973) counted as many as 250 egg masses on one tree. If the number of masses per tree average two or more, the pest outbreak can be expected the following year (Turček 1956; Vakula et al. 2015), but critical numbers should be considered based on the forest age and health status (Patočka 1961).

The number of eggs per egg mass varied from 343491 (Novotný, 1986) to 500-1000 (Turček 1949a; 1956). Turček (1949a; 1956) assumed 500-600 eggs are an average value. Hoch et al. (2001) reported similar numbers (averaging 534 eggs per egg mass) from Klingenbach (Austria, $60 \mathrm{~km}$ southwest of the Slovakia's border).

The gypsy moth overwinters as eggs. Larvae hatch from the middle of April (Novotný 1986; Vakula et al. 2015; Zúbrik et al. 2020a). After hatching, they rest several days on the surface of egg mass and then crawl to the crown on sunny days or balloon if the weather is windy (Patočka 1961). Airborne spread of larvae can be up to $15 \mathrm{~km}$ by wind (Novotný 1986). The larva (Fig. 2) has 5-6 instars, depending on sexes, that are relatively easy to determine by external morphological characters (Patočka 1954; Gogola 1969). Larvae start to feed in the crown at the beginning of May, defoliation culminates in mid-June (Fig. 3). They co-occur with other abundant species of leaf feeding caterpillars, such as Archips xylosteana L. and Orthosia spp. ("dispar-xylosteana complex") (Kulfan et al. 2018). Larvae pupate (Fig. 2) in late June and early July. The pupal stage lasts two weeks (Novotný 1986; Vakula et al. 2015; Zúbrik et al. 2020a). Swarming starts in the earlier part of July and culminates in its second half and eggs are laid in early August. At the beginning of September, no living adults are seen in forests (Turček 1949a; Novotný 1986).

\section{Hosts to the gypsy moth}

Gypsy moth hosts in Europe vary somewhat depending on how its distribution corresponds to the predominant vegetation in various geographical regions. There are slight differences in the gypsy moth food preferences between North, Central and southern Europe (Schopf et al. 1999; Švestka 1993, 1994, 2004; Hirka 2006; Csóka \& Hirka 2009; McManus \& Csóka 2007).

The gypsy moth is a highly polyphagous species, not only in Slovakia, but also in the whole territory of its occurrence (Kurir 1953; Janković 1958; Jahn \& Sinreich 1957; Fuester et al. 1983; Novotný 1986; Zúbrik et al. 2013). In Eurasia, gypsy moth larvae are able to consume about 90 different tree species, while in the United States 

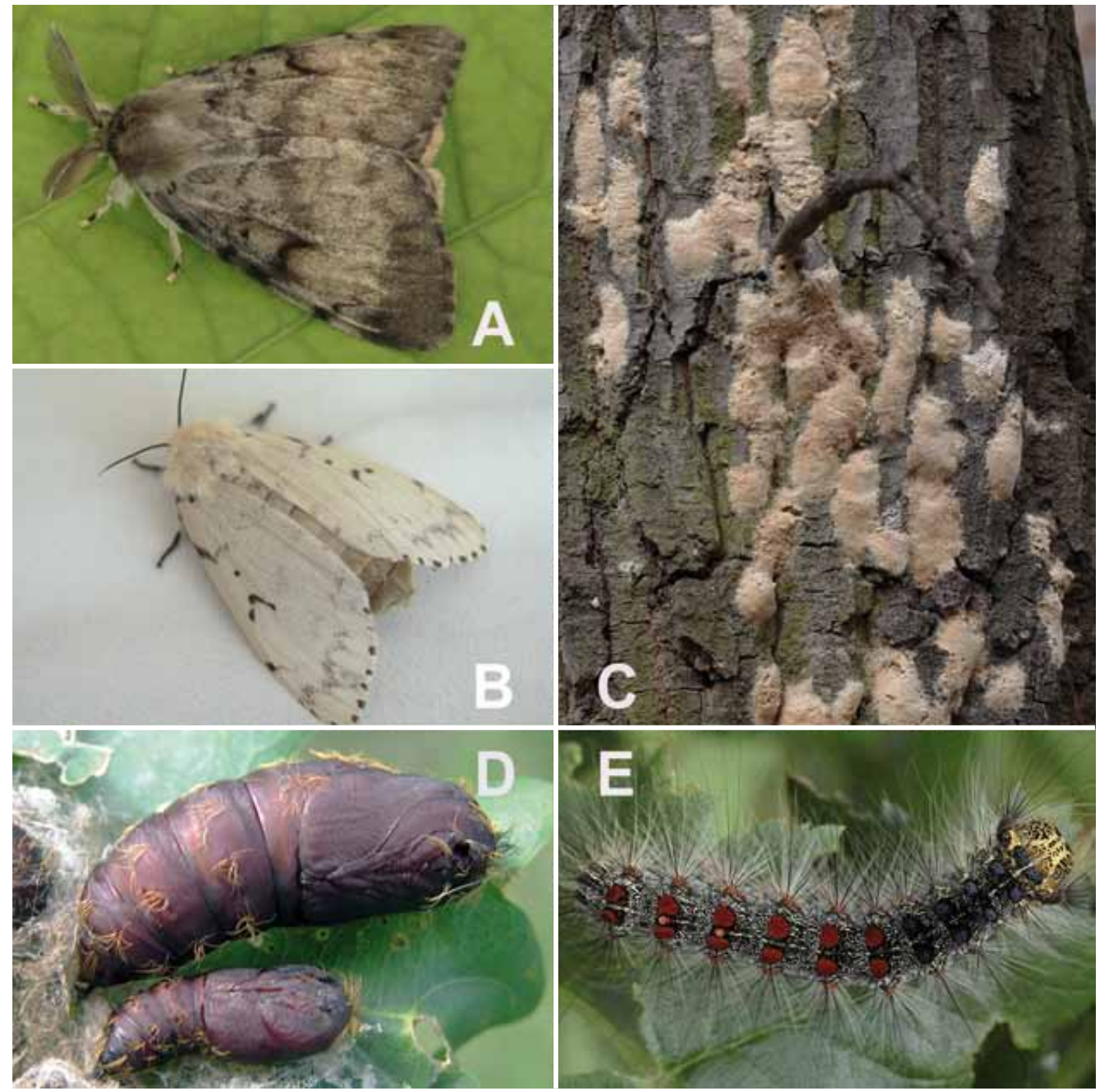

Fig. 2. Gypsy moth stages A) male, B) female, C) egg masses, D) pupae, E) larva in a final instar.

it is about 85 species (Schedl 1936; Doane \& McManus 1981). Wellenstein \& Schwenke (1978) state that up to 300 host plants have been recorded worldwide. It seems that younger larvae prefer mainly oak, possibly other trees with soft leaves, and only older instars are more polyphagous (Patočka 1970; Novotný 1986).

In Slovakia, larvae cause defoliation mostly in oaks (Quercus cerris L., Q. robur L., Q. petraea (Matt.) Liebl., Q. pubescens Willd.) (Tab. 1), but they can also feed on other trees and shrubs such as Carpinus betulus L., Acer spp., Robinia pseudoacacia L., Prunus spp., Crataegus spp., Malus sylvestris Mill., Pyrus communis L., Tilia spp., Populus spp., Betula spp. as well as others (Turček 1956; Patočka 1973; Stolina 1985; Novotný 1986) (Table 1).

In Slovakia, Q.cerris (Fig. 3) seems to be the most preferred food source (Turček 1953; Patočka 1961; Stolina
Table 1. Area defoliated by the gypsy moth in years 2002 , and 2004-2006, by tree species, according to the official statistics (Varínsky et al. 2003; Kunca et al. 2005, 2006, 2007, 2008).

\begin{tabular}{lcc}
\hline \multicolumn{1}{c}{ Tree species } & Area damaged (in hectares) & $\%$ \\
\hline Quercus spp. & 38,099 & 91.09 \\
Carpinus betulus & 2,492 & 5.96 \\
Robinia pseudoacacia & 743 & 1.78 \\
Fagus sylvatica & 417 & 1.00 \\
Populus spp. & 72 & 0.17 \\
Tilia spp. & 2 & 0.00 \\
Acer spp. & 1 & 0.00 \\
Alnus spp. & 1 & 0.00 \\
\hline Total & 41,827 & 100.00 \\
\hline
\end{tabular}

1985; Novotný 1986). Laboratory experiments showed that gypsy moth populations developed faster, and its larvae and pupae gained more weight on $Q$. cerris than on $Q$. petraea. Q. cerris females also laid significantly more eggs than those from Q. petraea. Field studies demon- 

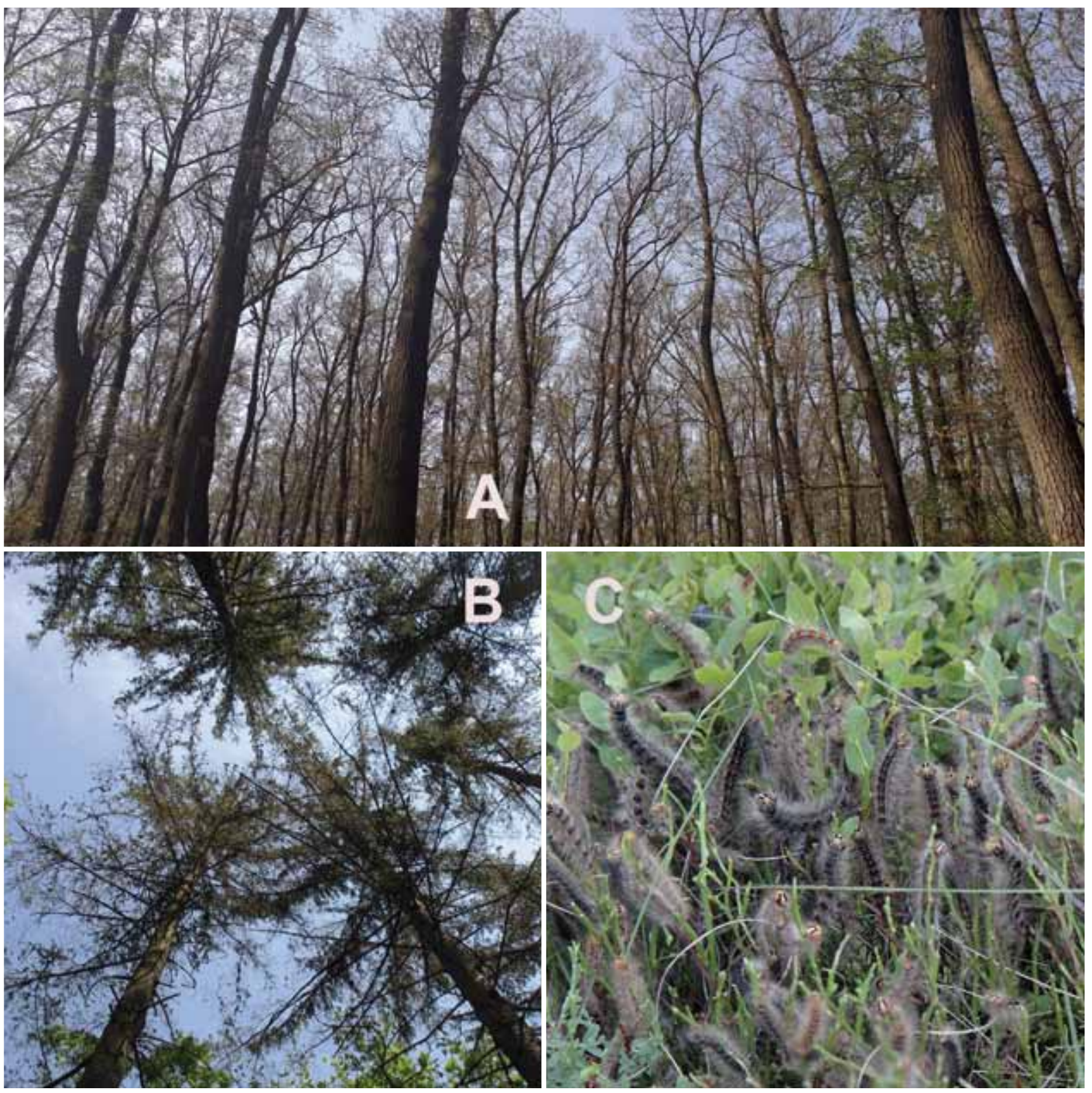

Fig. 3. A) Defoliation of Q. cerris stands by the gypsy moth are often severe; Šenkvice, June 2019. B) Defoliation of the spruce trees in 2018 (Vraná nad Vltavou, Czechia) documents gypsy moth is a highly polyphagous species. C) Unusual phenomenon in Slovakia: defoliation of Vaccinium myrtillus by the gypsy moth in a meadow habitat in 2011-2012 and 2020.

strated as well, a much faster development with less mortality of the caged gypsy moth larvae feeding on Q. cerris compared to those on Q. petraea (Schopf et al. 1999). In Slovakia, there is about 174,500 hectares of forests with prevalence of oak (Green report 2019) (Fig. 5).

Some tree species remain completely or partially untouched during gypsy moth outbreaks, like Loranthus europaeus Jacq., Fraxinus excelsior L., Fraxinus ornus L., Ligustrum vulgare L. and Morus alba L. (Turček 1956; Novotný1986). This is not the same everywhere, as some local insect pest populations may have different feeding preferences (Patočka 1973).

Coniferous trees are also usually untouched; however, taken individually in oak forests, they can be heavily defoliated too (Fig. 3). Novotný (1986) reported defoliation of Picea abies L., Abies alba Mill., Larix decidua Mill., Pinus sylvestris L., Pseudotsuga menziesii Mirb. and Pinus strobus L. Some conifers, as P. abies or P. silvestris, occurred in mixed forests were heavily defoliated by the gypsy moth in 2018 and 2020 in Slovakia and Czechia (Zúbrik, Liška, personal observation). In Slovakia, beech (Fagus sylvatica L.) was defoliated only on a relatively restricted area (Patočka 1967b; Novotný 1986), unlike neighbouring Hungary, where forests of it had heavy defoliation on large areas in the past (Csóka et al. 2015).

In 2011-2012, and again in 2020, approximately 0.25 ha of meadows ( 600 m a.s.l.) near Banská Štiavnica in Slovakia covered by Vaccinium myrtillus L. (Fig. 3) was 
completely defoliated, along with Sorbus spp., Salix spp., Malus sylvestris as well as $P$. abies and $P$. sylvestris growing solitary in that area (Zúbrik, personal observation). Damages to fruit tree plantations, vineyards and even agricultural crops (Zea mays L.) were also reported in the past from Slovakia (Turček 1949a, 1956; Patočka 1973; Leontovyč et al. 1980; Novotný 1986; Alford 2010).

\section{Natural enemy complex of the gypsy moth}

In spring, some egg masses eaten by unknown predators are often seen in forests (personal experiences). It seems that predation may play a meaningful role, especially during the latency period. Inversely, density-dependent relationship (between the gypsy moth egg mass density and the predation) was found, but this was not significant (Turčáni et al. 2003). About 30\% mortality in eggs is caused by birds as predators, such as Certhia familiaris L., Sitta europaea L., Parus major L., Cyanistes caeruleus L. and Aegithalos caudatus L. (Turček 1949a). The gypsy moth larvae may fall into the diet of several bird species in forests. However, they appear to be barely able to reduce the population density of this pest (Krištín 1999).

There are two egg parasitoids present on the territory of Slovakia, native Anastatus disparis Ruschka and Ooencyrtus kuwanae How (Hymenoptera: Eupelmidae), originating in Asia. Both species were released in that country at certain sites between 1960 and 1965 (Čapek 1966, 1971). They were successfully recorded again between 1985 and 1988 (Novotný \& Čapek 1989) and also later, from 1992 until 1995 (Zúbrik \& Novotný 1997), although, parasitisation rates were low, varying from 1 to $3 \%$.

The natural enemy complex is much broader in the larval and pupal stages than in the egg stage. In total,
28 insect species from the orders Hymenoptera and Diptera and one nematode were recorded during the investigation in 1991-1996. Species like tachinids Parasetigena silvestris R.-D. and Blepharipa pratensis Meig., braconids Cotesia melanoscelus Ratz., Phobocampe spp., and Glyptapanteles liparidis Bouché were the most important (Hoch et al. 2001). A broad range of insect parasitoids was also confirmed by other authors (Čapek et al. 1969; Čapek 1988; Zúbrik 1997; Turčáni et al. 2001). At latency sites, $C$. melanoscelus was the dominant species, followed by Phobocampe spp. and P. sylvestris. The oligophagous tachinids $P$. silvestris, $B$. pratensis and braconid $G$. liparidis were the dominant parasitoids at sites of outbreaks and pro-outbreaks (Zúbrik 1997; Hoch et al. 2001). About $20 \%$ of larvae investigated were killed by parasitoids. Mortality by pathogens was higher more than $30 \%$ (Hoch et al. 2001). That of larvae by pathogens during the culmination stage can reach even $60 \%$ (Novotný 1989). The most frequently occurring pathogen, which has been present in Slovakia, is the Lymantria dispar multicapsid nuclear polyhedrosis virus (LdMNPV). LdMNPV is considered the main reason for the collapse of the gypsy moth outbreak in 1949 (Charvát 1967). Other pathogens, such as Bacillus thuringiensis Berliner, Beauveria bassiana (Bals.-Criv.) Vuill., Nosema serbica Weiser and Nosema lymantriae Weiser were also recorded (Novotný 1989; Zúbrik 1997; Hoch et al. 2001). The exotic entomopathogenic fungus Entomophaga maimaiga Humber, Shimazu \& Soper was found in Slovakia for the first time in 2013 (Zúbrik et al. 2014). Further study revealed that the fungus was relatively widely spread here (Zúbrik et al. 2018b). It was suggested as well that it is spreading from the Balkan Peninsula (Zúbrik et al. 2016). Field study conducted in Slovakia during the years of 2014-2017 documented a narrow host range of E. maimaiga. Therefore, significant negative effects on the native lepidopteran fauna are not expected to occur (Zúbrik et al. 2018a).

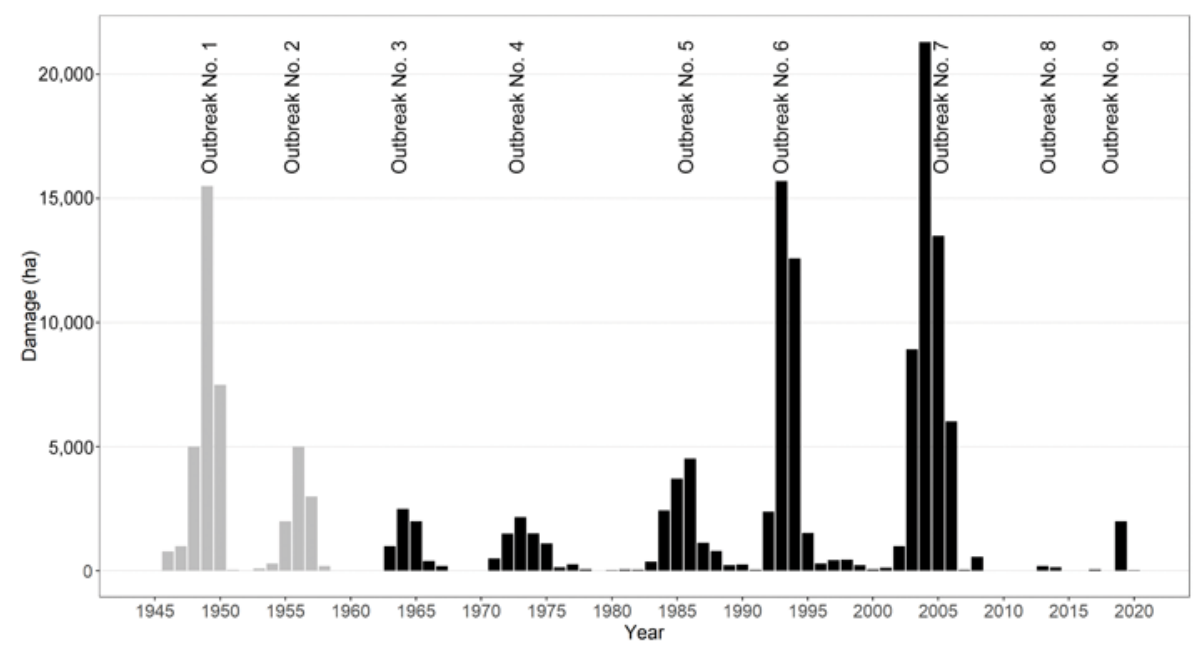

Fig. 4. Area damaged by the gypsy moth during the period from 1945 to 2020 . Period from 1945 to 1960 is coloured in different shade. In this way we wanted to point out, that information we had available about gypsy moth population density in the period up to 1960 is less accurate and not very detailed. While information after 1960 is more accurate and quite comprehensive. 
Predation on pupae was also investigated. It shows that small mammals may play an important role in pupal mortality (Turčáni et al. 2001). Invertebrate predation on gypsy moth caterpillars and pupae can also be a major mortality factor, mainly Calosoma sycophanta L. and Calosoma inquisitor L. (Coleoptera: Carabidae) frequently seen in forests during an outbreak period (Zúbrik, personal observations), but they have not yet been systematically studied as predators of larvae in Slovakia.

Outbreak situation influences in a different way forest ecosystems. Structure of natural enemies has changed (Hoch et al. 2001). Impact of defoliation on the presence of plant diseases was also confirmed (Patočka \& Novotný 1985). The number of birds increased 1.5 to 2 times during the outbreak period (Turček 1956).

\section{Dynamics of the gypsy moth population}

According to our analyses, there were nine gypsy moth outbreaks on the territory of Slovakia since 1945 (Table 2, Fig. 4). Over the period of 1945-2020, 155,034 ha of deciduous forests were touched with varying intensity, representing an average annual damage of 2,040 ha. The strongest outbreak was recorded in 2000-2008. Totally 51,479 ha were attacked during that period (Tab. 2). The year with the greatest damage intensity was in 2004, when 21,304 ha were attacked. On average, 17,226 ha were affected per one outbreak. We have found outbreak periods in Slovakia that repeat with frequency of $7.8 \pm$ 2.2 years and the average outbreak phase lasts $3.1 \pm$ 1.1 years overall. This value agrees with previous studies of Patočka (1954), Novotný (1986). Novotný (1986) was speaking about an outbreak period of three years. Sometimes local outbreaks collapse faster from different reasons, after one or two years (Patočka 1973; Zúbrik et al. 2020a). Only 4 outbreaks were included into the data analyse in Hlásny et al. (2015), and also outbreak period, not outbreak phase was used in analyse. In our study, 9 outbreaks and outbreak phase was used. This difference caused, our results slightly differ from those published by Hlásny et al. (2015).

We tried to construct a trend for the length of the outbreak phase and the length of the period between two outbreak peaks (outbreak frequency) (Fig. 6). The trend indicates the period between two subsequent outbreaks seems to be more or less constant and duration of the outbreak phase seems to be gradually shortened during the study period. However, the coefficient of determination is very low in both cases. The shortening of the length of the outbreak phase may be related to the appearance of the fungus E. maimaiga. Several circumstances suggest that $E$. maimaiga has affected the length of gradation in 2013-2014 and 2017-2020 significantly (Zúbrik, personal observation).

There are some traditional areas for gypsy moth outbreaks on Slovakia's territory that do not change too much over time (Fig. 5). These regions are, such as the following: 1) the western part of the country, around Pezinok, Modra, Šenkvice, Bratislava; 2) around Nitra, Čifáre, Levice and Nové Zámky; 3) around Velký Krtíš, Rimavská Sobota and Lučenec; and 4) eastern Slovakia, around Michalovce, Ortov and Sobrance (Pfeffer 1961; Patočka 1961, 1973; Charvát 1967; Kunca et al. 2005, 2006, 2007; Zúbrik et al. 2019). Gypsy moth outbreaks usually start in the western and central parts of the country, and then slowly shift to the East (Turček 1956; Charvát 1967; Zúbrik et al. 2019). We tried to confirm this statement on an example of the outbreak in 2002-2007 (Fig. 7). Defoliation in 2002 was reported only from western part of Slovakia and defoliation in eastern part clearly occurs first only after 3 year in 2005 and continued to 2006 .

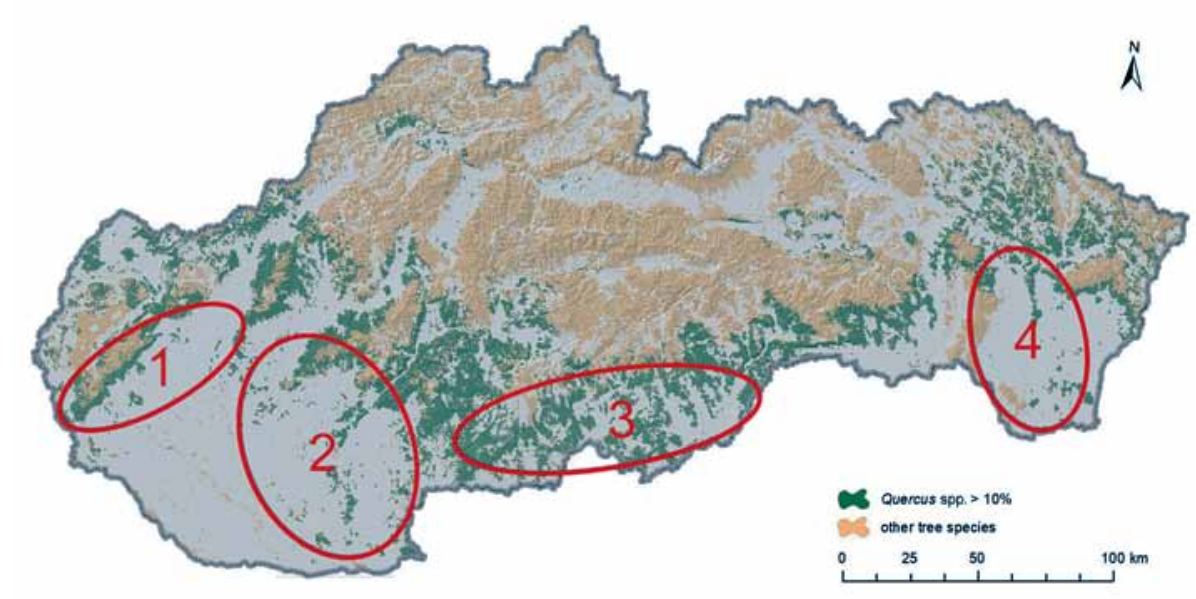

Fig. 5. Map showing the distribution of all oak forest types in Slovakia (only those with more than $10 \%$ of oak in composition were considered as oak forest). Very schematic indication of traditional areas for gypsy moth outbreaks on Slovakia's territory (see description in text). 


\section{Outbreak No. 1:}

About this first, it was a very strong gypsy moth outbreak after World War II, reported Hendrych (1959). Patočka (1961) mentioned that there was damage to 30,00050,000 hectares during two outbreaks in 1946-1949 and then in 1954-1957. Charvát (1967) confirmed that about 30,000 ha were defoliated and it culminated in 1949 during the outbreak period of 1946-1949. He was speaking about a "large outbreak" in 1946-1949, comparing it with the one in 1953-1958, which he commented as a
Pezinok and Palárikovo. Also, Patočka (1961) mentioned this outbreak and dated it as 1954-1957. Years with very mild weather in 1952, 1954, 1955 and 1956 could have initiated this, which started in stands of Fageto-Quercetum and Carpineto-Quercetum under warmer climate. Outbreak culminated in 1956 and then the gypsy moth density was reduced, probably due to the unsuitable weather in 1957 and 1958. Charvát (1967) dated this oubreak approximately to the years 1953-1958.

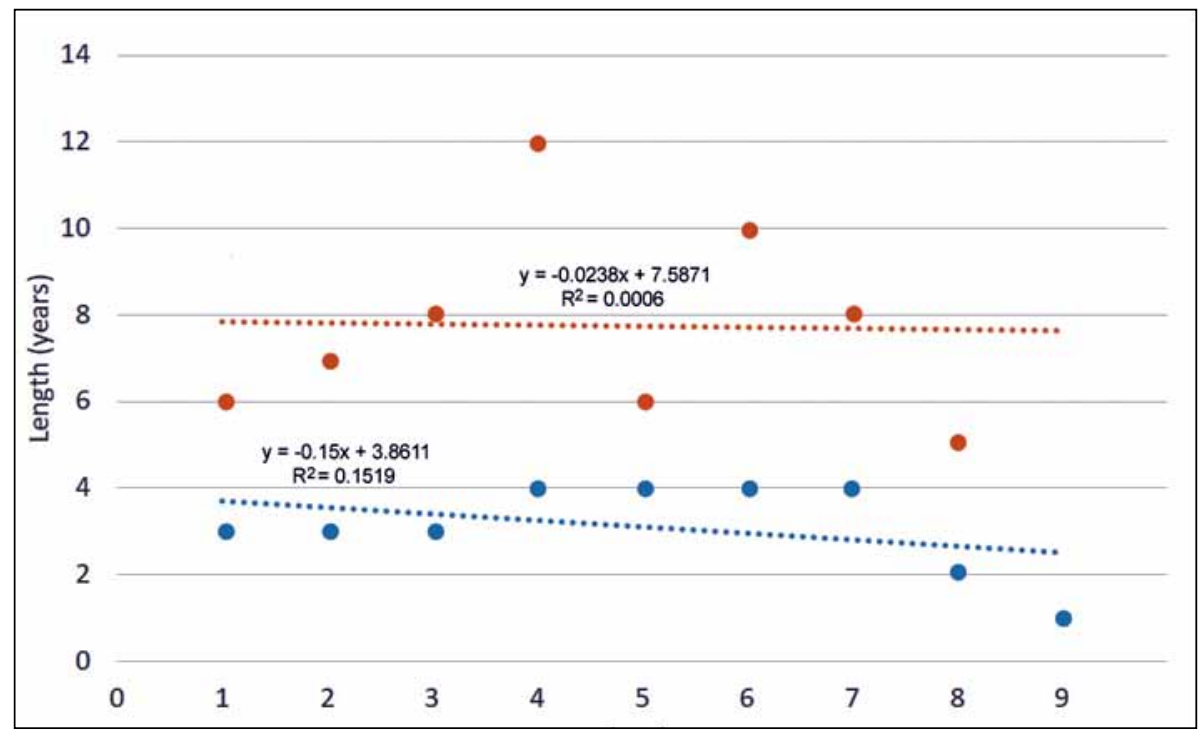

Fig. 6. The length of the outbreak phase (blue dots, 1-1948-1950, 2-1955-1957, 3-1963-1965, 4-1972-1975, 5-1984-1987, 6-1992-1995, 7-2003-2006, 8-2013-2014, 9-2019) and the length of the period between two outbreak peaks (red dots, 1-1949-1956, 2-1956-1964, 3-1964-1973, 4-1973-1986, 5-1986-1993, 6-1993-2004, 7-2004-2013, 8-2013-2019) with linear trends (duration of the outbreak phase - blue dotted line, duration of the period between two outbreak peaks - red dotted line). Trend lines were calculated using the method of least squares.

“smaller outbreak of local importance”. Patočka (1973) described outbreaks in 1946-1948 as "massive" and the subsequent two in 1954-1956 and 1964-1966 as "smaller ones". Turček (1950) and Konôpka (1978) also reported about a large, area-wide defoliation during this outbreak period. It was preceded by extremely dry and hot weather in 1947 . The defoliation started in western Slovakia and moved to eastern Slovak lowlands in subsequent years (Charvát 1967). Forests were especially damaged near Levice, Nitra, Lučenec, Šahy, Rimavská Sobota and Sobrance (Patočka 1953; Charvát 1967). Turček (1949a) described outbreaks at the local level, reporting total defoliation in 1946-1948. In 1949, after all primary food sources were consumed; hungry caterpillars caused damages even to agricultural crops (Patočka 1961).

\section{Outbreak No. 2}

Shortly about this outbreak, reported Pfeffer (1961), largest-scale defoliation was observed in 1955, near Šaštín-Stráže and Smolenice, as well as in 1956, near

\section{Outbreak No. 3}

Leontovyč et al. (1980) deeply discussed this period of 1963-1967. They reported complete defoliation near Pezinok, Palárikovo, Levice, Šahy, Lučenec and other areas. It is estimated that there was damage to about 2,000 ha annually during this one. Patočka (1967b) and Čapek et al. (1969) also noted this outbreak and dated it as 1963-1965, with an abundance reaching culmination in 1964. Čapek et al. (1969) studied larval parasitoids in the gypsy moth population and he therefore independently monitored the density of the latter on seven study plots. The results show that the number of gypsy moth egg masses has already increased in 1963 and their abundance culminated in 1964. Population was locally high even in 1965, but in 1966, it falls down to a low level, apparently also affected by cold spring weather (Patočka 1967b). In 1968, egg masses only occurred sporadically (Charvát 1969). 


\section{Outbreak No. 4}

Leontovyč et al. (1980) first dated this to the years 19711974. They mentioned a situation where 300 hectares, even of coniferous trees (Pinus spp., P. abies, Pseudotsuga spp.), were damaged. Patočka et al. (1999) recorded an increase in the gypsy moth density, also in that period, and confirmed the outbreak culminating in 1973-1975, with local occurrences in 1976 and 1977.) A very high pest density in the whole zone was observed in 1975, but in 1976 and 1977, only small outbreaks were reported and the damaged area was increasing from 145 ha in 1976 to 247 ha in 1977 (Surovec et al. 1989).

\section{Outbreak No. 5}

The exact data about this outbreak are provided by Surovec et al. (1989). It speaks about an outbreak where approximately 2,400-4,500 hectares were damaged on an annual basis, especially in Bratislava, and slightly less in the Banská Bystrica administrative district. First defoliations were already reported in 1983 (nearTesárske Mlyňany). In 1984, local occurrences were more frequent in every primary affected zone, nearby specifically Čifáre, Podhájska, Nitra and Žitavany. In 1985 and 1986, there was area-wide defoliation reaching impressive intensity. Significant reduction in abundance was found in 1986 and local outbreaks became scarce in 1987. Outbreak period had a low-range peak in 1986. These data were also confirmed by analysing the official statistical evidence from the state forest (Zúbrik et al. 2013). Patočka et al. (1999) dated this outbreak to the years 1984-1987 too.

\section{Outbreak No. 6}

The period that was warm and dry at the beginning of the nineties of the last century (especially the year 1992) contributed to the rapid progress of the gypsy moth outbreak in 1993 and 1994 (Zúbrik 1998). Novotný \& Turčáni (1993) reported previously in 1992 some changes in the population density. The infested area already reached more than 2,000 hectares in 1992, with a tendency to further increase. Outbreak culminated in 1993, and very high level of infestation remains in 1994. The most damaged areas were close to Nitra, Levice, Malé Karpaty, Košice and Prešov. In 1995, damages were not so extensive. In 1996, the gypsy moth population was in latency; a local outbreak in the area of about 200 ha was recognised (Zúbrik \& Turčáni 1997).

\section{Outbreak No. 7}

The pest population density rose slightly in 2002 followed by a very fast increase in 2003 . The outbreak started in the western part of the country and progress to the East (Fig. 7). In 2004, already 21,304 ha were defoliated by the gypsy moth, mainly around Nitra and Levice (Kunca et al. 2005). As for $2005,13,498$ ha were damaged, primarily in the vicinity of Velký Krtíš, Krupina, Lučenec as well as Bratislava and Nové Zámky (Kunca et al. 2006, 2007, 2008; Zúbrik 2006). Aerial applications of insecticides were realised on a territory of 29,831 ha in 2004-2006. Approximately 7,000 hectares were defoliated (officially 6,025 ha) in 2006 (Kunca et al. 2006). Kunca et al. (2007) were speaking about the end of the outbreak in 2007, when only a very restricted area was damaged (45 ha) and no application was made. They concluded that this was the largest gypsy moth outbreak during the last 50 years. It was exceptionally severe not only in Slovakia, but also in many other EU countries. Hungary, for example, reported record-breaking damages to 212,000 hectares starting from 2005 (Csóka \& Hirka 2009), while in Croatia the gypsy moth affected 33,000 ha in this particular year (Hrašovec et al. 2008). Švestka (2004) observed a large gypsy moth outbreak in the neighbouring Czechia in 2003 and 2004. He expected that defoliation will continue in 2005 .

\section{Outbreak No. 8}

This is very unusual outbreak and after consideration, we decided to keep it here, despite it does not fulfil all criteria for a typical outbreak period. In 2011, in certain areas, a high number of gypsy moth larvae and adults was found in the oak forests. During autumn 2011, high amount of gypsy moth egg masses in oak stands was confirmed. A further significant rise in population densitywas expected in 2012. However, this did not occur (Zúbrik et al. 2013). In 2013, defoliation was recognised on about 200 ha in some isolated "spots" (for example, near Ortov in the eastern part of Slovakia) (Kunca et al. 2014). In 2014, about 150 ha was defoliated (Kunca et al. 2015, 2016). Adetailed monitoring of the gypsy moth population density confirmed these observations; it slightly increased in 2011-2013. As for 2014, there was a fast decline into a

Table 2. Outbreaks overview in the period 1945-2020.

\begin{tabular}{|c|c|c|c|c|c|c|}
\hline No. of outbreak & Outbreak peak & Outbreak & $\begin{array}{l}\text { Hectares defoliated } \\
\text { during outbreak }\end{array}$ & Outbreak phase & $\begin{array}{c}\text { Hectares defoliated } \\
\text { during outbreak phase }\end{array}$ & Control methods used \\
\hline 1 & 1949 & $1946-1951$ & 29,822 & $1948-1950$ & 28,000 & Dynocid (DDT) \\
\hline 2 & 1956 & $1953-1958$ & 10,600 & $1955-1957$ & 10,000 & Dynocid (DDT) \\
\hline 3 & 1964 & $1963-1967$ & 6,100 & $1963-1965$ & 5,500 & no data available \\
\hline 4 & 1973 & $1971-1978$ & 7,268 & $1972-1975$ & 6,278 & no data available \\
\hline 5 & 1986 & 1979-1990 & 13,588 & 1984-1987 & 11,799 & B. thuringiensis + growth regulators \\
\hline 6 & 1993 & 1991-1999 & 33,639 & 1992-1995 & 32,210 & B. thuringiensis + growth regulators \\
\hline 7 & 2004 & $2000-2008$ & 51,579 & $2003-2006$ & 49,758 & B. thuringiensis + growth regulators \\
\hline 8 & 2013 & 2013-2014 & 350 & $2013-2014$ & 350 & B. thuringiensis \\
\hline 9 & 2019 & 2017-2020 & 2,053 & 2019 & 2,000 & no control realised \\
\hline Total (ha) & & & 155,034 & & 145,925 & \\
\hline
\end{tabular}




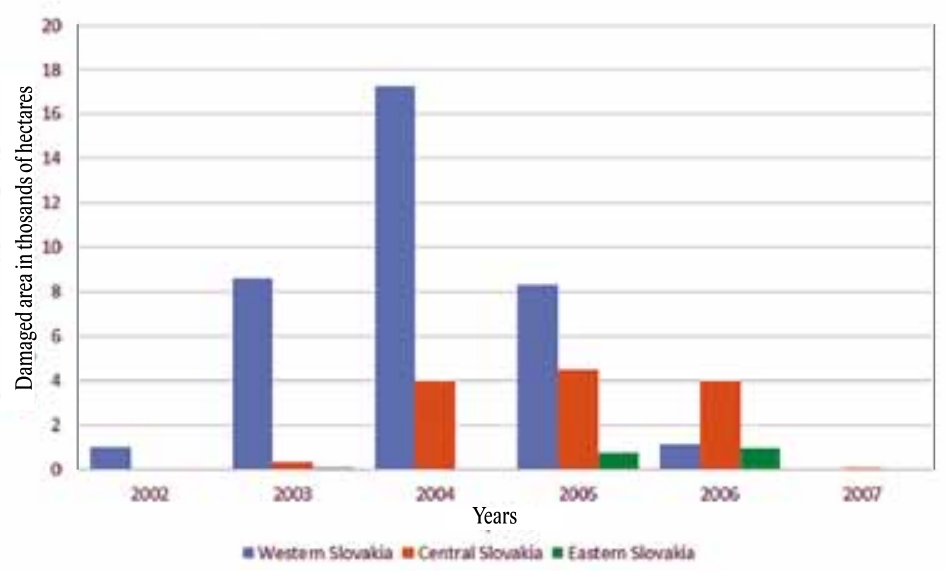

Fig 7. Area damaged by the gypsy moth from 2002 to 2007 in different geographical parts of Slovakia, demonstrating, that the defoliation started in the western part of the country and progress to the East.

latency stage (Zúbrik, unpublished data). Despite these changes were only occurring at low levels and were not recognised so significantly at a "macro" one, we do consider them as a gypsy moth outbreak. In the same years, quite strong-evidence outbreaks were also reported in some other European countries (Tabaković-Tošić 2015).

\section{Outbreak No. 9}

In 2018, the gypsy moth population density again has increased significantly in many places and a new outbreak started (Zúbrik et al. 2019). Data from a detailed monitoring confirmed, that gypsy moth population density was very high in 2018 in an area of 2,418 ha, although no significant damage was reported (Kunca et al. 2019a, 2019b). Zúbrik et al. (2019) expected that about 2,000 to 4,000 ha were going to be damaged in 2019 , the outbreak will continue to reach a peak in 2020, and gradually decline in 2021. Despite high defoliation occurring in 2019 in some areas, most of the gypsy moth larvae died at the beginning of June 2019 infected by E. maimaiga. Very cold and wet conditions in May can be a predisposing factor for strong activity of fungi (Zúbrik et al. 2020a, 2020 b). This situation resulted in only 91 ha which were officially reported as damaged in 2019 , but the area defoliated by the gypsy moth was in reality definitely larger, estimated at a level of 2000 ha (Zúbrik et al.2020b). Only very few local areas of the country are staying with high gypsy moth population density in 2020 . One of these was a forest near Párovské Háje (Nitra region). Field observations confirmed almost no defoliation in Slovakia caused by the gypsy moth in 2020 (Zúbrik, personal observation). In neighbouring Czechia about gypsy moth outbreak in this period reports Liška (2018).

\section{Causes of the origin and the collapse of gypsy moth outbreaks}

There are generally several factors determining outbreaks of leaf-eating insects. Some are pest's density-dependent (food source, natural enemies, etc.) and some are pest's density-independent (temperature, wind, humidity, rainfall, etc.) (Clark et al. 1967; Barbosa \& Schultz 1987).

Gypsy moth outbreaks come, according to some authors, mostly after years of warm weather, as well as balanced climate in May and without late frost during spring months in Slovakia (Patočka 1973; Novotný 1986; Kunca et al. 2013). We can also discuss how much was the decline in pest population density, affected with a heavy, late frost occurring in southern Slovakia - on April 18 2012, was measured $-9.4{ }^{\circ} \mathrm{C}$ (Kunca et al. 2013). Patočka (1967b) stated that spring weather in April and May could have a very significant impact on pest abundance. However, it seems that most of these statements were just expert estimations and were not seriously supported by field experiments. Not any deeper research was done on the territory of Slovakia to assess the impact intensity of individual climate factors on gypsy moth population dynamics.

We addressed temperature and precipitation trends, analysing data from 26 meteorological stations in the area of gypsy moth outbreaks (Fig. 8). So far, we have not made a statistical comparison between the trend in population dynamics and that of precipitation and temperature. It is likely that some deeper analysis is needed to estimate more precisely this influence. It seems that another factor or more than one could deteriorate the population dynamics besides these two. Definitely more research and investigation is required in this area.

Natural enemy complex plays an important role in population dynamics of pests (Novotný 1989; Hoch et al. 2001). In 2013, E. maimaiga was found for the first time in Slovakia (Zúbrik et al. 2014). The impact of this fungus on the L. dispar population should not be underestimated since that time, especially when certain indications are suggesting it was introduced a few years earlier, as was finally recognised (Zúbrik et al. 2014, 2016, 2018b). Zúbrik et al. (2016) stated that interactions between E. maimaiga and gypsy moth population dynamics can 
be very strong. This entomopathogenic fungus can even lead to the collapse of its outbreak. Further observation documented that local outbreaks in the country were very heavily attacked by $E$. maimaiga (near Šenkvice, Párovské Háje, Čifáre, etc.) in 2019 as in 2020, and it was clearly responsible for fast collapse of outbreaks occurring locally (Zúbrik et al. 2020a; Zúbrik personal observation). It can be assumed that due to E. maimaiga, gypsy moth outbreaks should reach a lesser intensity in the future and be more local compared to the past.

Genetic predisposition and food quality are also important (Patočka 1973). Patočka (1973) concluded that outbreaks in Slovakia will occur only during particularly favourable years and in the most suitable areas. In experiments with manipulated water availability, gypsy moth larvae consumed much more leaves (birch Betula pendula) and the food conversion efficiency was lower, if food comes from plots with no watering (Castagneyrol et al. 2018). However, the growth rate of these larvae was the same for both types of experimental plots, watered and non-watered. These results suggest that larvae compensated the low quality of leaves from areas with no watering by consuming larger amounts of them. Adaptation to lower food quality in drought conditions generally leads to greater consumption, which is accompanied with more tree damage (Jactel et al. 2012).

\section{Impacts of defoliation on forests}

Generally, direct defoliation-induced tree mortality is ever lower, even in sensitive forests, compared to that caused bywind, snow or bark beetles (Kunca etal. 2019b). Some authors pointed out its impacts on radial growth, presence of secondary pests (Agrilus spp., S. intricatus, Armillaria spp., etc.) and the one on coniferous trees, which is typically negative (Turček 1950; Patočka 1974;
Novotný 1986; Novotný \& Surovec 1992; Csóka \& Hirka 2009).

Novotný (1986) divided the tree species into several categories regarding their responses to the defoliation caused by the gypsy moth. The most resistant ones, such as $Q$. cerris, Tilia spp. or Prunus spp., can completely replace their foliage within about 60 days. Impacts of defoliation on the health of trees used to be more severe if repeated for two or three consecutive years and if it is combined with dry and hot weather conditions.

Defoliated trees have reduced annual stem growth; they are less tolerant to water stress and easily attacked by secondary pests (Patočka et al. 1999; Nakajima 2015; Camarero et al. 2018, 2019). The Turkey oak evidently had the best recovery potential (Csóka et al. 2015). It almost totally replaced its lost foliage in four months after severe defoliation by gypsy moth caterpillars in western Hungary. The pedunculate oak and beech needed two years to reach the same level of recovery. This first species used to suffer from a heavy infection of powdery mildew Erysiphe alphitoides, following defoliation, which may slow down tree recovery (Csóka et al. 2015; Zúbrik et al. 2020a). Defoliation can be fatal in case of seedlings (Patočka 1973).

Impact of defoliation on plant production can also be very important, mainly in areas where natural regeneration is expected. There was almost no crop output occurring in heavily defoliated stands (Turček 1956; Novotný 1986). Similar impact of it on acorn production is known in North America (McConnell 1988).

Patočka (1973) was also speaking about reducing the recreational value of forests during gypsy moth outbreaks. The invasion of large, hairy caterpillars in the recreation area of Pata, during the pest outbreak of 1972-1973, caused problems to forest visitors and residents in the area.

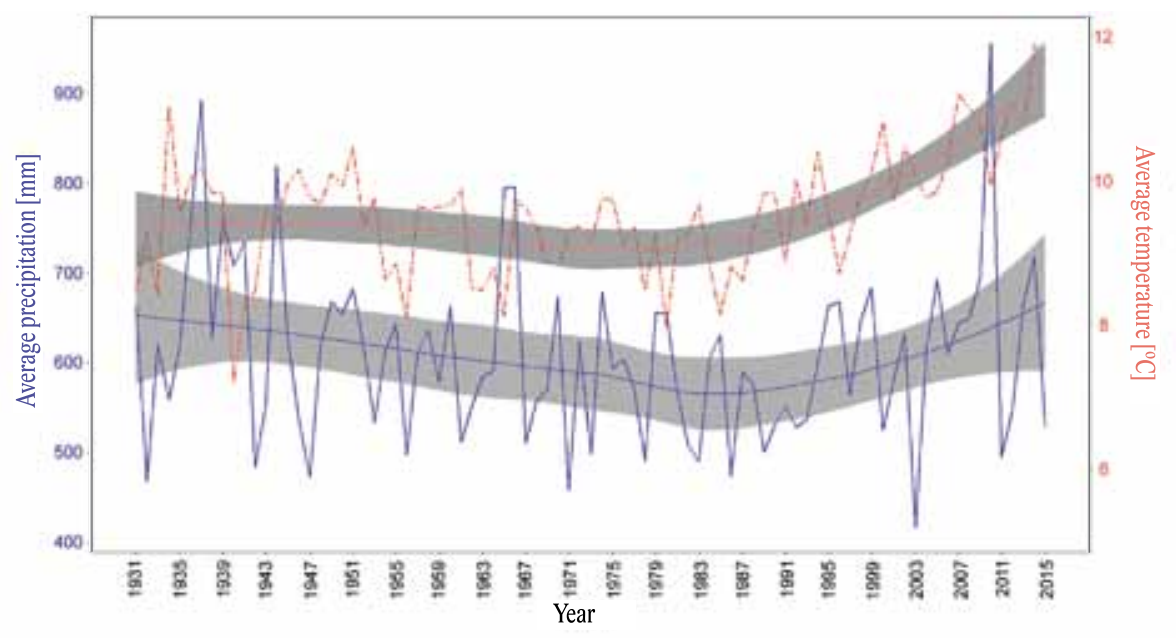

Fig. 8. Development of mean annual temperatures $\left({ }^{\circ} \mathrm{C}\right)$ and annual precipitation (mm) in the period of 1931-2015 calculated as an average values from 26 weather stations of Slovak Hydrometeorological Institute (SHMI). Mean annual temperatures and precipitations were smoothed using smoothed conditional means - local polynomial regression fitting. Grey background behind smooth represents standard error with $95 \%$ confidence intervals. 


\section{Previous and current methods of control}

Intense applications of Dynocid (DDT) against gypsy moth larvae were realised in the past in Slovakia. Several authors reported about large aerial applications during the outbreak of 1946-1949 (Turček et al. 1950; Patočka 1973; Konôpka 1978). Later on, forests were treated by insecticide (DDT), about 5,000 ha were in 1955, 4,000 in 1956, and 6,000 in 1957 (Kudler et al. 1958). Some authors observed negative effects of DDT on natural enemies and environment (Turček 1949b; Patočka 1973).

Patočka (1961) discussed a possible control method based on collecting and destroying egg masses. This is more ecologically friendly but less effective, compared to chemical applications against larvae. As a disadvantage, this procedure is considering that part of these masses can be overlooked and many are in inaccessible areas in the crown.

Since the 60's and the 70's of the last century, intense experimentation with biological agents against gypsy moth larvae was realised in Slovakia. As the most promising one, $B$. thuringiensis was tested in several trials (Hešková 1978; Novotný 1985, 1988a, 1988b; Novotný \& Švestka 1986, Turčáni 2001). Larval mortality was high and full efficiency was reached after 2-8 days of treatment, depending on the dose (Novotný 1988b, 1989). Besides B. thuringiensis, also LdMNPV (Novotný 1985, 1989), B. bassiana (Novotný 1989), viruses (Švestka \& Pultar 1997) and microsporidia (Weiser \& Novotný 1987; Hoch et al. 2008; Solter et al. 2010) have been tested against the gypsy moth on the territory of Slovakia.

As a result of this intense research in the field of biomonitoring, gypsy moth outbreaks were almost exclusively managed with biological and biotechnical preparation since 1984-1987. Insecticide formulations based on $B$. thuringiensis were used on 1,126 hectares ( $24 \%$ of total 5,878 ha sprayed) during those years (Novotný 1988a). In order to prevent damage in 1992-1995, extensive aerial applications were also realised. B. thuringiensis-based bioinsecticides and insect growth inhibitors (e.g. Dimilin) were applied on a territory over 15,000 hectares (Turčáni \& Zúbrik 1997; Zúbrik 1998). In the period of 2004-2006 (three years) applications from the air were even more intense. From the total treated area $(29,831$ hectares; 8,298 ha in $2004,15,955$ in $2005,5,538$ in 2006), the biological preparation based on $B$. thuringiensis (Biobit XL) was used on 6,637 ha (22.2\%). Growth regulators were for the remaining 23,194 ha $(77.8 \%)$. Aerial applications were financially covered by the Ministry of Agriculture and co-financed by State Forest Enterprises. Their cost reached c. 365,000 EUR in 2004, c. 740,000 EUR in 2005, and c. 170,000 EUR in 2006 (Zúbrik \& Kovalčík 2005; Zúbrik 2006; Zúbrik et al. 2006). In 2019, applications from the air against the gypsy moth on a territory of about 3,000 hawere planned, while B. thuringiensis Biobit XL was proposed exclusively (Zúbrik et al. 2019). They were not realised yet, partially due to a restriction from the State Nature Conservancy officials and also to high mortality of the larvae by E. maimaiga (Zúbrik et al. 2020a). The applications were usually taken place in the spring, between May 5 and 20 (Zúbrik 2004).

\section{Conclusions}

This is the most complete and most detailed reconstruction of the gypsy moth population dynamics on the territory of Slovakia, although some partial reconstruction was already compiled and published (Zúbrik et al. 2013; Kunca et al. 2013, 2014; Hlásny et al. 2015; Zúbrik et al. 2017a). We have included these works in our assessment, and they have been filled with new, until now unanalysed data.

- There were nine gypsy moth outbreaks since 1945. In the period of 1945-2020,155,036 ha were damaged with varying intensity. The strongest outbreak was in 2000-2008 when 51,579 ha were attacked. On average, 17,226 ha were affected per one outbreak period. We have found outbreak periods that repeat with frequency of $7.8 \pm 2,2$ years and the average outbreak phase lasts $3.1 \pm 1,1$ years. The outbreak started in the western part of the country and progress to the East. The period between two subsequent outbreaks seems to be more or less constant and the duration of the outbreak seems to be gradually shortened during the study period.

- There are several factors influencing the gypsy moth population density in Slovakia. For example, weather in May, late frosts, genetic predisposition, natural enemy complex and food quality are considered by many authors as key ones. Unfortunately, most published statements were just an expert estimation and were not sufficiently supported by field experiments.

- Gypsy moth is extremely polyphagous species in the country; however, Q. cerris seems to be the most preferred host.

- Defoliated trees have reduced annual stem growth; they are less tolerant to water stress and easily attacked by secondary pests.

- Intense applications of Dynocid (DDT) against gypsy moth larvae were realised in the past. Gypsy moth outbreaks were almost exclusively managed with biological and biotechnical preparation since 1984 .

- The exotic entomopathogenic fungus E. maimaiga was found in Slovakia for the first time in 2013. Certain circumstances suggest that, due to E. maimaiga, gypsy moth outbreaks should reach a lesser intensity in the future and will be more local compared to the past. 


\section{Acknowledgements}

This research was supported by the Slovak Research and Development Agency (APVV) via grants No. APVV-0707-12, APVV14-0567, APVV-15-0531, APVV-15-0348, APVV-16-0325, $A P V V$-19-0116andAPVV-19-0119, the Scientific GrantAgency VEGA via grants No. VEGA2/0012/17, VEGA2/0032/19 and also by the European Regional Development Fund (ERDF) via Project No. 313011X531 "Development of biologically and biotechnically oriented systems of forest protection against domestic and non-native (invasive) organisms". This work also received support from the Ministry of Defence of the Slovak Republic via project VLMSR0120 and from the Ministry of Agriculture and Rural Development of the Slovak Republic via the project SLOVLES. Also supported by Ministry of Agriculture of the Czech Republic via institutional support MZE-RO 0118. The authors thank Dominique Fournier (Canada) for linguistic and editorial improvements.

\section{References}

Alford, D. V., 2010: Pests of fruit crops. Boston, Academic Press, $461 \mathrm{p}$.

Barbosa, P., Schultz, J. C., 1987: Insect Outbreaks. New York, Academic Press, 578 p.

Camarero, J. J., Alvarez-Taboada, F., Hevia, A., CastedoDorado, F., 2018: Radial growth and wood density reflect the impacts and susceptibility to defoliation by gypsy moth and climate in radiata pine. Frontiers in Plant Science. Available on: https://doi.org/10.3389/ fpls.2018.01582.

Camarero, J. J., de Andrés, E. G., Sangüesa-Barreda, G., Rita, A., Colangelo, M., 2019: Long-and short-term impacts of a defoliating moth plus mistletoe on tree growth, wood anatomy and water-use efficiency. Dendrochronologia, 56:1-9.

Castagneyrol, B., Moreira, X., Jactel, H., 2018: Drought and plant neighbourhood interactively determine herbivore consumption and performance. Scientific Reports, 8:1-11.

Charvát, K. 1969: Výskyt škodlivých činitel'ov v lesnom hospodárstve na Slovensku v roku 1968.

Charvát, K., 1967:Kalamitné výskyty škodlivých činitelov v lesnom hospodárstve na Slovensku v období po druhej svetovej vojne a perspektívy protikalamitného boja. In: IV. vedecká konferencia VÚLH, Zvolen, 14 p.

Charvát, K., Patočka, J., 1960: K priebehu kalamity obal'ovačov „Choristoneura murinana Hb. a Epinotia nigricana H.S.) v jedlinách Stredného Pohronia. Vedecké práce VÚLH v B. Štiavnici, 1:213-229.

Clark, L. R., Geier, P. W., Hughs, R. D., Morris, R. F., 1967: The ecology of insect populations in theory and practice. London, Methuen and Co. Ltd., 232 p.

Csóka, G., Hirka, A., 2009: Gyapjaslepke (Lymantria dispar L.) legutóbbi tömegszaporodása Magyarországon. Növényvédelem, 45:196-201.
Csóka, G., Pödör, Z., Nagy, G., Hirka, A., 2015: Canopy recovery of pedunculate oak, Turkey oak and beech trees after severe defoliation by gypsy moth (Lymantria dispar): Case study from Western Hungary. Central European Forestry Journal, 61:143-148.

Čapek, M. et al., 1969: Výskum entomopatogénnych článkonožcov kalamitných škodcov lesných drevín. Zvolen, VÚLH, R-VII-3/1, 21 p.

Čapek, M., 1961: Kalamita obal'ovača smrekovcového Zeiraphera diniana Guen. na smreku v oblasti prašivej. Lesnícky časopis, 7:260-271.

Čapek, M., 1966: Doterajšie skúsenosti s introdukciou vaječných parazitoidov mníšky velkohlavej Lymantria dispar L. z južnej Európy. In: Možnosti využití biologického boje v ochraně zemědělských plodin a lesních kultur. Souhrn referátů zvědeckého semináře, Praha, UVTI MNLH, p. 47-51.

Čapek, M., 1971: Výsledky pokusov s introdukciou vaječných parazitov mníšky velkohlavej na Slovensku. Lesnícky časopis, 17:127-137.

Čapek, M., 1988: The braconidae (Hymenoptera), as parasitoids of the gypsy moth (Lymantria dispar L. Lepidoptera). Acta Instituti Forestalis Zvolenensis, 7:79-91.

Davidson, C. B., Gottschalk, K. W., Johnson, J. E., 1999: Tree mortality following defoliation by the European gypsy moth (Lymantria dispar L.) in the United States: a review. Forest Science, 45:74-84.

Doane, C. C., McManus, M. L. (eds.), 1981: The gypsy moth: Research toward integrated pest management. USDA For. Serv. Sci. Educ., Washington D. C., Agriculture Technical Bulletin 1584, 757 p.

Fuester, R. W., Drea, J. J., Gruber, F., Hozer, H., Mercadier, G., 1983: Larval parasites and other natural enemies of Lymantria dispar (Lepidoptera: Lymantriidae) in Burgenland, Austria, and Wurzburg, Germany. Environmental Entomology, 12:724-737.

Gogola, E., 1969: Určovanie instaru húseníc mníšky vel'kohlavej (Lymantria dispar L.). Zborník vedeckých prác Lesníckej fakulty VŠLD Zvolen, 11:83-97.

Gottschalk, K. W., 1990: Gypsy moth effects on mast production. In: McGee, C. E. (eds.): Proceedings of the Workshop: Southern Appalachian Mast Management, University of Tennessee, Knoxville, p. 42-50.

Green report 2019: Available on: https://www.mpsr.sk/ zelena-sprava-2019/123---14927/ (27.10.2020)

Hendrych, V., 1959: Ochrana lesov. Bratislava, Slovenské vydavatel'stvo pôdohospodárskej literatúry, 311 p.

Hešková, A., 1978: Bacullus thuringiensis Berl. v boji proti mníškevelkohlavej Lymantria dispar L. Vedecké práce VÚLH Zvolen, 26:171-198.

Hirka, A., 2006: A 2005 évi biotikus és abiotikus erdőgazdasági károk, valamint a 2006-ban várható károsítások. Budapest, Hungarian Forest Research Institute, $124 \mathrm{p}$. 
Hlásny, T., Trombik, J., Holuša, J., Lukášová, K., Grendár, M., Turčáni, M. et al., 2015: Multi-decade patterns of gypsy moth fluctuations in the Carpathian Mountains and options for outbreak forecasting. Journal of Pest Science, 89:413-425.

Hoch, G., D’Amigo, V., Solter, L., Zúbrik, M., McManus, M., 2008: Quantifying horizontal transmission of Nosemalymantriae, a microsporidian pathogen of the gypsy moth, Lymantria dispar (Lep., Lymantriidae) in field cage studies. Journal of Invertebrate Pathology, 2:146-150.

Hoch, G., Zúbrik, M., Novotný, J., Schopf, A., 2001:The natural enemy complex of the gypsy moth, Lymantria dispar (Lep., Lymantriidae) in different phases of its population dynamics in eastern Austria and Slovakia - a comparative study. Journal of Applied Entomology, 125:17-227.

Hrašovec, B., Pernek, M., Matoševič, D., 2008: Spruce, fir and pine bark beetle outbreak development and gypsy moth situation in Croatia in 2007. Forstschutz Aktuell, 44:12-13.

Jactel, H., Petit, J., Desprez-Loustau, M. L., Delzon, S., Piou, D., Battisti, A., Koricheva, J., 2012: Drought effects on damage by forest insects and pathogens: a metaanalysis. Global Change Biology, 18:267-276.

Jahn, E., Sinreich, A., 1957: Beobachtungen zum Auftreten des Schwammspinners (Lymantria dispar L.) des Goldafters (Euproctis chrysorrhoea L.) und des grünen Eichenwicklers (Tortrix viridana L.) in Niederöstereich und in Burgenland in den Jahren 1952 bis 1956. Anzeiger für Schädlingskunde, 30:139-146.

Janković, L., 1958: Forest plants of the gypsy moth (Lymantria dispar L.) in the open in the course of a single gradation. Biol. Inst. N.R., Serbia, 2:1-15.

Konôpka, J., 1978:Vývoj výskumu ochrany lesa. Vedecké práce VÚLH Zvolen, 28:155-172.

Krištín, A., 1999: Vögel als Vertilger der Schmetterlinge. In: Patočka, J., Krištín, A., Kulfan, J., Zach, P. (eds.): Die Eichenschädlinge und ihre Feinde. Institut für Waldökologie der SAV, Zvolen, p. 327-335.

Kudler, J., Kalandra, A., Kolubajiv, S., Pivetz, B., 1958: Poprašování a zamlžovánív ochranělesů ČSR. Praha, SZN, 74 p.

Kulfan J., Sarvašová L., Parák M., Dzurenko M., Zach P., 2018: Can late flushing trees avoid attack by moth larvae in temperate forests? Plant Protection Science, 54:272-283.

Kunca, A., Dubec, M., Galko, J., Gubka, A., Konôpka, B., Leontovyč, R. et al., 2019a: Problémy ochrany lesa v roku 2018 a prognóza na rok 2019. In: Kunca, A. (eds.): Aktuálne problémy ochrany lesa 2018. NLC, Zvolen, p. 17-22.

Kunca, A., Brutovský, D., Find'o, S., Konôpka, J., Leontovyč, R., Longauerová, V. et al., 2005: Výskyt škodlivých činitelov v lesoch Slovenska za rok 2004 a ich prognóza na rok 2005. Zvolen, Lesnícky výskumný ústav Zvolen, 90 p.
Kunca, A., Brutovský, D., Find'o, S., Gubka, A., Konôpka, B., Konôpka, J.etal., 2006:Výskyt škodlivých činitel'ov v lesoch Slovenska za rok 2005 a ich prognóza na rok 2006. Zvolen, NLC, 89 p.

Kunca, A., Baláž, P., Brutovský, D., Find'o, S., Gubka, A., Konôpka, B. et al., 2007: Výskyt škodlivých činitel'ov v lesoch Slovenska za rok 2006 a ich prognóza na rok 2007. Zvolen, NLC 101 p.

Kunca, A., Baláž, P., Brutovský, D., Find'o, S., Gubka, A., Konôpka, B. et al., 2008: Výskyt škodlivých činitel'ov v lesoch Slovenska za rok 2007 a ich prognóza na rok 2008. Zvolen, NLC, 101 p.

Kunca, A., Find'o, S., Galko, J., Gubka, A., Kaštier, P., Konôpka, B. et al., 2014: Výskyt škodlivých činitelov v lesoch Slovenska za rok 2013 a ich prognóza na rok 2014. Zvolen, NLC, 88 p.

Kunca, A., Find'o, S., Galko, J., Gubka, A., Kaštier, P., Konôpka, B. et al., 2015: Výskyt škodlivých činitel'ov v lesoch Slovenska za rok 2014 a ich prognóza na rok 2015. Zvolen, NLC, 109 p.

Kunca, A., Zúbrik, M., Vakula, J., Galko, J., Konôpka, B., Leontovyč, R. et al., 2016:Výskyt škodlivých činitel'ov v lesoch Slovenska v rokoch 1960-2014 v roku 2015 a prognóza ich vývoja. Zvolen, NLC 139 p.

Kunca, A., Zúbrik, M., Vakula, J., Galko, J., Konôpka, B., Leontovyč, R. et al., 2019b: Výskyt škodlivých činitel'ov v lesoch Slovenska za rok 2018 a prognóza ich vývoja na rok 2019. Zvolen, NLC, 92 p.

Kunca, A., Find'o, S., Galko, J., Gubka, A., Kaštier, P., Konôpka, B. et al., 2013: Problémy ochrany lesa v roku 2012 a prognóza na rok 2013. In: Kunca, A. (eds.): Aktuálne problémy v ochrane lesa 2013. Zvolen, NLC, p. 19-28.

Kurir, A., 1953: The food plant of the gypsy moth (a contribution to the knowledge of its feeding habits). Zeitschrift für Angewandte Entomologie, 34:543586.

Leontovyč, R., Brutovský, D., Húska, P., Olha, F., Konôpka, J., Patočka, J. et al., 1980: Hlavné škodlivé činitele v lesoch Slovenskej socialistickej republiky. Lesnícke štúdie, 32:94 p.

Liška, J., 2018: Výskyt bekyní v roce 2018. Lesnická práce, 10:52-53.

McConnell, S. P., 1988: Effects of gypsy moth defoliation on acorn production and viability, litterfall, and litter layer depth and biomass in northcentral Virginia and western Maryland. Maste r's thesis, Virginia Polytechnic Institute and State University, Virginia, Blacksburg, $123 \mathrm{p}$.

McManus, M., Csóka, G., 2007: History and impact of gypsy moth in North America and comparison to the recent outbreaks in Europe. Acta Silvatica et Lignaria Hungarica, 3:47-64.

Muzika, R. M., Liebhold, A. M., 1999: Changes in radial increment of host and nonhost tree species with gypsy moth defoliation. Canadian Journal of Forest Research, 29:1365-1373. 
Nakajima, H., 2015: Defoliation by gypsy moths negatively affects the production of acorns by two Japanese oak species. Trees, 29:1559-1566.

Novotný, J., 1985: Modern methods of gypsy moth (Lymantria dispar L.) control in the forest of Slovakia. In: Biological and biotechnological control of forest pests. Proceedings of the Nation Wide Conference, September 10-12. 1985, Tábor, 66 p.

Novotný, J., 1986: Nový charakter kalamity mníšky velkohlavej (Lymantria dispar L.) v lesoch Slovenska. Zprávy lesnického výskumu, 31:26-29.

Novotný, J., 1988a: Biopreparáty v praktickej ochrane lesa. Zprávy lesnického výskumu, 33:16-19.

Novotný, J., 1988b: Časový priebeh účinnosti bakteriálnych prípravkov na húsenice Lymantria dispar L. Lesnícky časopis, 34:325-335.

Novotný, J., 1989: Bioregulovanie početnosti mníšky velkohlavej. Lesnícke štúdie, 46:107 p.

Novotný, J., Čapek, M., 1989: Distribution of Lymantria dispar (Lep., Lymantriidae) egg parasitoids (Hym., Chalcidoidea, Proctotrrupoidea) in Slovakia. Biológia, 44:933-939.

Novotný, J., Surovec, D., 1992: The effects of defoliation on oak decline. Acta Instituti Forestalis Zvolenensis, $8: 85-95$.

Novotný, J., Švestka, M., 1986: Spolupôsobenie biologických a chemických insekticídov na húsenice mníšky Lymantria dispar (L.). Lesnictví, 32:1115-1128.

Novotný, J., Turčáni, M., 1992: Feromónový monitoring motýlích škodcov lesa. Lesnícke štúdie, 50:118 p.

Novotný, J., Turčáni, M., 1993: Ohrozenie lesných porastov listožravým hmyzom. In: Surovec, D. (eds.): Ochrana lesov proti škodlivým činitelom. Zvolen, LVÚ Zvolen, p. 76-83.

Patočka, J., 1953: O housenkách škodících na dubech na Slovensku. Práce výzkumných ústavů lesnických ČSR, 9:121-142.

Patočka, J., 1954: Húsenice na duboch v ČSR. Bratislava, Štátne pôdohospodárske nakladatel'stvo, 264 p.

Patočka, J., 1955: Obal'ovač jedl'ový vážny škodca jedlín na Slovensku. Les, 2:184-191.

Patočka, J., 1961: Pred novou kalamitou mníšky velkohlavej (Lymantria dispar). Lesnícky časopis, 7:218-226.

Patočka, J., 1963a: Ohrozenost' dubových porastov na Slovensku listožravými Lepidopterami. Zprávy VÚLH, 1:9-15.

Patočka, J., 1963b: Piadivky ako škodcovia listnáčov na Slovensku. Lesnická práce, 42:214-225.

Patočka, J., 1967a: K bionómii a populačnej dynamike obalovačov Choristoneura murinana Hb. a Epinotia nigricana $\mathrm{H}$. S. na jedli na Slovensku. In: Otázky ochrany lesov na Slovensku. Bratislava, Vyd. SAV, p. 93-177.

Patočka, J., 1967b: O príčinách vzniku a zániku gradácií mníšky velkohlavej (Lymantria dispar L.) v Európe. In: IV. vedecká konferencia VÚLH, Zvolen, Z-I/1-7.
Patočka, J., 1970:Výskum populačnej dynamiky motýlov na drevinách.Záverečná správa.Zvolen, VÚLH,147p.

Patočka, J., 1973: Kalamita mníšky vel'kohlavej na území Lesnej správy Levice. Les, 29: 446-448.

Patočka, J., 1974: Ohrozenost' kvalitných dubín na Slovensku listožravými škodcami. Realizačný výstup výskumnej úlohy „Výskum populačnej dynamiky motýlov na drevinách“. Zvolen, VÚLH, 40 p.

Patočka, J., Krištín, A., Kulfan, J., Zach, P., 1999: Die Eichenschädlinge und ihre Feinde. Zvolen, SAV, $396 \mathrm{p}$.

Patočka, J., Novotný, J., 1985: Hmyz a jeho vplyv na hromadné hynutie dubov. Záverečná správa úlohy Výskum hromadného odumierania dubov. Zvolen, VÚLH, p. 80-112.

Pernek, M., Pilas, I., Vrbek, B., Benko, M., Hrasovec. B., Milkovic, J., 2008: Forecasting the impact of the gypsy moth on lowland hardwood forests by analyzing the cyclical pattern of population and climate data series. Forest Ecology and Management, 255:1740-1748.

Pfeffer,A., 1961: Ochrana lesů. Praha, Státní zemědělské nakladatelství, 838 p.

Sarvašová, L., Kulfan, J., Saniga, M., Zúbrik, M., Zach, P., 2020: Winter Geometrid Moths in Oak Forests: Is Monitoring a Single Species Reliable to Predict Defoliation Risk? Forests, 11:228.

Schedl, K. E., 1936: Der Schwammspinner in Euroasien, Afrika und Neuengland. Berlin, Verlagsbuchhandlung Paul Parey, $242 \mathrm{p}$.

Schopf, A., Hoch, G., Klaus, A., Novotný, J., Zúbrik, M., Schafellner, C., 1999: Influence of food quality of two oak species on the development and growth of gypsy moth larvae. In: Lieutier, F., Mattson, W.J., Wagner, M.R. (eds.): Physiology and Genetics of Tree-Phytophage Interactions. Paris, INRA, p. 231-247.

Solter, L., Pilarska, D., McManus, M., Zúbrik, M., Patočka, J., Huang,W. et al., 2010: Host specificity of microsporidia pathogenic to the gypsy moth, Lymantria dispar (L.): field studies in Slovakia. Journal of Invertebrate Pathology, 105:1-10.

Stolina, M., 1985: Ochrana lesa. Bratislava, Príroda, $480 \mathrm{p}$.

Surovec, D., Brutovský, D., Find'o, S., Hešková, A., Heško, J., Kocian, V. et al. 1989: Hlavné škodlivé činitele v lesoch SSR za roky 1975 - 1986. Lesnícke štúdie, 45:122 p.

Švestka, M., 1993: Gradace škodlivých motýlů z čeledi bekyňovitých. Lesnická práce, 72:145-147.

Švestka, M., 1994: Ohlédnutí za gradací bekyně velkohlavé. Lesnická práce, 73:5-7.

Švestka, M., 2004: Gradace bekyně velkohlavé (Lymantria dispar L.) na jižní Moravě v roce 2004. Zpravodaj ochrany lesa, 10:10-13.

Švestka, M., Pultar, O., 1997: Virové preparáty v ochraně lesa. Lesnická práce, 76:50-51. 
Tabaković-Tošić, M., 2015: Entomopathogenic fungus Entomophaga maimaiga and integrated pest management in Serbia. Communications in Agricultural and Applied Biological Sciences, 80:153-159.

Turčáni, M., 2001: The preliminary results of trials conducted with neem and combinations of neem and Bacillus thuringiensis var. kurstaki in gypsy moth (Lymantria dispar L) control in Slovakia. In: Metspalu, L., Mitt, S. (eds.): Practice oriented results on the use of plant extracts and pheromones in pest control. Tartu, p. 120-123.

Turčáni, M., Liebhold, A. M, McManus, M. L., Novotný, J., 2003: Preliminary results on predation of gypsy moth egg masses in Slovakia. In: Ecology, survey and management of forest insects. In: McManus, M. L., Liebhold, A. M. (eds.): General Technical Reports NE-311. U.S. Dept. of Agriculture, Forest Service, Northeastern Research Station, Newtown Square, PA. p. 115-120.

Turčáni, M., Novotný, J., Zúbrik, M., McManus, M., Pilarska, D., Maddox, J., 2001: The role of biotic factors in gypsy moth population dynamics in Slovakia: Present Knowledge. In: Liebhold, A. M., McManus, M. L., Otvos, I. S., Fosbroke, S. (eds.): Proceedings: Integrated Management and Dynamics of Forest Defoliating Insects. USDA, Northeastern Research Station, General Technical Reports, NE-xxx, p. 152-167.

Turčáni, M., Zúbrik, M., 1997: Defoliation of forest stands by leaf-eating insect in Slovakia during period 1972-1996. In: Knížek, M., Zahradník, P., Diviš, K. (eds.): Proceedings Workshop on Forest Insects and Disease Survey, Písek, p. 142-144.

Turček, F., 1949a: O populácii vtákovv listnatých lesoch pri premnožení bekyne velkohlavej (Lymantria dispar L.). Zprávy Státních výskumných ústavů lesních ČSR, 108-131.

Turček, F., 1949b: Insekticídy, herbicídy, fungicídy a ochrana prírody. Ochrana prírody, 4:73-76.

Turček, F., 1950: Zpráva o výskytu lesných škodcov na Slovensku v roku 1947 a 1948. Lesnická práce, 29:9-18.

Turček, F., 1953: K otázke bekyne vel'kohlavej (Lymantria dispar L.) ako lesného škodcu na Slovensku. Pol'ana, 9:35-37.

Turček, F., 1956: Mníška vel'kohlavá. Bratislava, SVPL, $57 \mathrm{p}$.

Turček, F., Patočka, J., Pašek, V., 1950: Letecké poprašovanie s DDT (Gesarol) proti bekyni velkohlavej (Lymantria dispar L.) na Slovensku. Pol'ana, 6:8-10.

Vakula, J., Zúbrik, M., Kunca, A., Dubec, M., Findo, S., Galko, J. et al., 2015: Nové metódy ochrany lesa.Zvolen, NLC, 292 p.
Varínsky, J., Brutovský, D., Find'o, S., Konôpka, J., Kunca, A., Leontovyč, R. et al., 2003: Výskyt' škodlivých činitel'ov v lesoch Slovenska za rok 2002 a ich prognóza na rok 2003. Zvolen, LVÚ Zvolen, $119 \mathrm{p}$.

Weiser, J., Novotný, J., 1987: Field application of Nosema lymantriae against the gypsy moth, Lymantria dispar L. Journal of Applied Entomology, 104:58-62

Wellenstein, G., Schwenke, W., 1978: Lymantria Hbn. In: Schwenke, W.: Die Forstschädlinge Europas III. Band Schmetterlinge. Hamburg und Berlin, Paul Parey, 334-368.

Zach, P., 1994: Floeo- a xylofágne chrobáky (Coleoptera) v dubových lapákoch na lesostepnom stanovišti. Lesnícky časopis - Forestry Journal, 4:249-257.

Zúbrik, M., 1997: The study of gypsy moth, Lymantria dispar L. (Lep., Lymnatriidae) natural enemies complex, with special reference to the parasitoids. $\mathrm{PhD}$ thesis, Zvolen, TU Zvolen, $110 \mathrm{p}$.

Zúbrik, M., 1998: Súčasný stav a perspektívy vývoja populácií listožravého a cicavého hmyzu na Slovensku. In: Varínsky, J. (eds.): Aktuálne problémy v ochrane lesa 98. Zvolen, LVÚ Zvolen, p. 89-95.

Zúbrik, M., 2004: Mníška velkohlavá Lymantria dispar (L.) najvýznamnejší defoliátor dubín. In: Varínsky, J. (eds.): Aktuálne problémy v ochrane lesa 2004. Zvolen, LVÚ Zvolen, p. 130-141.

Zúbrik, M., 2006: Mníška vel'kohlavá v 3. roku - záver gradácie a prognóza vývoja v nasledujúcich rokoch. In: Varínsky, J. (eds.): Aktuálne problémy v ochrane lesa 2006. Zvolen, NLC, p. 109-114.

Zúbrik, M., Barta, M., Pilarska, D., Goertz, D., Uradník, M., Galko, J. et al., 2014: First record of Entomophaga maimaiga in Slovakia. Short communication. Biocontrol Science and Technology, 24:710-714.

Zúbrik, M., Hajek, A., Pilarska, D., Špilda, I., Georgiev, G., Hrašovec, B. et al., 2016: The potential for Entomophaga maimaiga to regulate gypsy moth Lymantria dispar (L.) (Lepidoptera: Erebidae) in Europe. Journal of Applied Entomology, 140:565-579.

Zúbrik, M., Kajba, M., Kunca, A., Nikolov, Ch., Úradník, M., Rell, S., 2013: Monitoring mníšky velkohlavej v roku 2012 a prognóza vývoja pre najbližšie obdobie. In: Kunca, A. (eds.): Aktuálne problémy v ochrane lesa 2013. Zvolen, NLC, p. 70-76.

Zúbrik, M., Kovalčík, J., 2005: Kalamita mníšky velkohlavej, stav, predpoklad vývoja a realizácia obranných opatrení. In: Kunca, A. (eds.): Aktuálne problémy v ochrane lesa 2005. Zvolen, LVÚ Zvolen, p. 117-122. 
Zúbrik, M., Kunca, A., Galko, J., Rell, S., Vakula, J., Leontovyč, R. et al., 2019: Mníška velkohlavá a opatrenia na zabránenie vzniku vel'koplošnej kalamity v rokoch 2019-2021. In: Kunca, A. (eds.): Aktuálne problémy v ochrane lesa 2019. Zborník referátov z medzinárodnej konferencie konanej 31.-1.2.2019 v Kongresovom centre Kúpel'ov Nový Smokovec, Zvolen, NLC, p. 55-62.

Zúbrik, M., Kunca, A., Rell, S., Galko, J., Nikolov, Ch., Leontovyč, R. et al., 2017a: Výskyt listožravých a cicavých hmyzích škodcov v lesoch Slovenska v období 1960-2015. In: Kunca, A. (eds.): Aktuálne problémy v ochrane lesa 2017, Zvolen, NLC, p. $54-70$.

Zúbrik, M., Longauerová, V., Kunca, A., Leontovyč, R., Strmeň, S., Vakula, J. et al., 2006: Správa o účinnosti leteckých ošetrení proti mníške velkohlavej realizovaných v rokoch 2004-2006. Zvolen, NLC, 8 p.

Zúbrik, M., Novotný, J., 1997: Egg parasitization of Lymantria dispar (Lep., Lymantriidae) in Slovakia. Biológia, 52:343-350.

Zúbrik, M., Novotný, J., Turčáni, M., Leontovyč, R., 1999: The dominant pests and injurious agents in Slovakia. In: Forster, B., Knížek, M., Grodzki, W. (eds.): Methodology of Forest Insect and Disease Survey in Central Europe. Swiss Federal Institute for Forest, Snow and Landscape Research (WSL), p. 36-41.

Zúbrik, M., Pilarska, D., Kulfan, J., Bartad, M., Hajek, A. E., Bittner, T. D. et al., 2018a: Phytophagous larvae occurring in Central and Southeastern European oak forests as a potential host of Entomophaga maimaiga (Entomophthorales: Entomophthoraceae) - A field study. Journal of Invertebrate Pathology, 155:52-54.
Zúbrik, M., Rell, S., Holuša, J., 2020b: Listožravý a civavý hmyz v lesoch Slovenska v roku 2019. APOL, 1:148-152.

Zúbrik, M., Rell, S., Kunca, A., Galko, J., Nikolov, Ch., Leontovyč, R., et al., 2017b: Hrebenáky na borovici, metódy kontroly a ochrany. In: Kunca, A. (ed.), Aktuálne problémy v ochrane lesa 2017. Zvolen, NLC, p. 31-35.

Zúbrik, M., Rell, S., Kunca, A., Galko, J., Vakula, J., Leontovyč, R. et al., 2020a: Listožravé druhy škodcov na Slovensku (v evidencii a v lesných porastoch) a premnoženie mníšky vel'kohlavej v roku 2018 2019. APOL, 1:21-27.

Zúbrik, M., Špilda, I., Pilarska, D, Hajek, A. E., Takov, D., Nikolov, C. et al., 2018b: Distribution of the entomopathogenic fungus Entomophaga maimaiga (Entomophthorales: Entomophthoraceae) at the northern edge of its range in Europe. Annals of Applied Biology, 173:35-41.

Zúbrik, M., Turčáni, M., 1997: Premnoženie listožravého hmyzu v dubinách a ohrozenie lesných porastov defoliátormi v roku 1997. In:Varínsky, J. (eds.):Aktuálne problémy v ochrane lesa 97. Zvolen, LVÚ Zvolen, p. 97-107.

Zúbrik, M., Vakula, J., Rell, S., Kunca, A., Galko, J., Nikolov, Ch. et al., 2015: Výskyt listožravých škodcov na Slovensku v roku 2014 a prognóza ich výskytu na rok 2015. In: Kunca, A. (eds.): Aktuálne problémy v ochrane lesa 2015. Zvolen, NLC, p. 47-54. 